\title{
Ciclismo e comércio em Manaus, 1898-1907
}

\section{Race biking and commerce at Manaus, 1898-1907 \\ Cleber Dias* \\ Eliza Salgado de Souza*}

\begin{abstract}
Resumo
Este artigo analisa a história do ciclismo em Manaus entre os anos 1898 e 1907. Datam desse período o início das primeiras iniciativas para a prática desta modalidade na cidade, bem como a construção de dois espaços (velódromos) especialmente dedicados a esse esporte. Desde essa época, o ciclismo em Manaus esteve organizado fundamentalmente como um empreendimento comercial. Nesse sentido, o comércio foi um aspecto bastante importante para o início da difusão de esportes em Manaus.
\end{abstract}

Palavras-chave: História; Economia; Esporte; Brasil; Manaus.

\begin{abstract}
This article analyzes the history of cycling in Manaus between 1898 and 1907. This period marks the beginning of the first initiatives to practice this sport in the city, as well as the construction of two spaces (velodromes) especially dedicated to this sport. Since that time, cycling in Manaus has been organized as a commercial enterprise. In this sense, commerce was a very important aspect for the beginning of the diffusion of sports in Manaus.
\end{abstract}

Keywords: History; Economics; Sport; Brazil; Manaus.

\section{Introdução}

A historiografia brasileira dos esportes está bastante concentrada em uma única modalidade, que é o futebol. ${ }^{2}$ Trata-se do predomínio de uma

\footnotetext{
${ }^{1}$ Este estudo contou com apoio da Coordenação de Aperfeiçoamento de Pessoal de Nível Superior (CAPES). *É professor da Universidade Federal de Minas Gerais, no Programa de Pós-Graduação Interdisciplinar em Estudos do Lazer. E-mail: cleberdiasufmg@gmail.com

** Mestre em Estudos do Lazer pela Universidade Federal de Minas Gerais. E-mail: elizasalgado7@gmail.com ${ }^{2}$ TORRES, Cesar R. South America. In: POPE, S. W; NAURIGHT, John. (eds.). Routledge companion to sports history. New York: Routledge, 2009, p. 553-569; MELO, Victor Andrade de. 0 trato do esporte nos simpósios
} 
visão retrospectiva que toma para a análise histórica apenas os esportes que preponderaram sobre todos os outros ao longo do século 20. No entanto, visto sob o ponto de vista da transição entre os séculos 19 e 20, período que testemunhou o início da consolidação histórica dos esportes como um costume progressivamente disseminado no Brasil, o triunfo do futebol não estava de forma alguma garantido ainda. Naquela época, modalidades como o remo, o turfe ou o ciclismo eram as que gozavam de maior entusiasmo popular. ${ }^{3} \mathrm{Com}$ efeito, seria difícil prever naquela época que o futebol se tornaria depois tão hegemônico nos gostos populares, como de fato se tornou.

Outra concentração que gera assimetrias prejudiciais ao conhecimento histórico sobre os esportes no Brasil é a ênfase sobre o estudo de certas regiões, em detrimento de várias outras, que são sistematicamente negligenciadas. Regra geral, estudos históricos sobre os esportes costumam dedicar-se, sobretudo, as capitais do Rio de Janeiro, de São Paulo, de Minas Gerais, do Paraná e do Rio Grande do Sul. Mais eventualmente, notam-se também estudos sobre algumas capitais do Nordeste, como Salvador, Recife, Fortaleza e Natal. As regiões Norte e Centro-Oeste do país, de outro modo, recebem pouquíssima atenção. Essa concentração regional das pesquisas implica negativamente todo o debate historiográfico desse campo de estudos. A ignorância a respeito do desenvolvimento histórico dos esportes em regiões cultural, econômica ou politicamente periféricas do Brasil pode ser apontada como um dos principais

da Associação Nacional de História (Anpuh). Recorde, v. 9, n. 1, p. 1- 17, jan./ jun. 2016.

${ }^{3}$ MELO, Victor Andrade de. Cidadesportiva: primórdios do esporte no Rio de Janeiro. Rio de Janeiro: RelumeDumará / Faperj, 2001; SCHETINO, André. Pedalando na modernidade: a bicicleta e o ciclismo na transição do século XIX para o XX. Rio de Janeiro: Apicuri, 2008; GAMBETA, Wilson. A bola rolou: o velódromo paulista e os espetáculos de futebol. São Paulo: SESI-SP editora, 2015; SOUZA, João Paulo Ribeiro de. Modernidade, esporte e lazer na cidade da Parahyba do Norte, 1908-1925. Dissertação (Mestrado em História). Campinas Grande: Universidade Federal de Campina Grande, 2014; VIEIRA, Carla Manuela da Silva. Sociabilidade e modernidade nos espaços de lazer da capital cearense no início do século XX (1901 a 1910). Dissertação (Mestrado em História). São Paulo: Pontifícia Universidade Católica de São Paulo, 2012; PORTO, Tiago Cavalcante. As transformações do lazer em Fortaleza (1910-1930). Fortaleza: Universidade Estadual do Ceará, Fortaleza, 2015; ROCHA JUNIOR, Coriolano P. da. Esporte e modernidade: uma análise comparada da experiência esportiva no Rio de Janeiro e na Bahia nos anos finais do século XIX e iniciais do século XX. Tese (Doutorado em História Comparada). Rio de Janeiro: Universidade Federal do Rio de Janeiro, 2011; COUCEIRO, Sylvia Costa. Artes de viver a cidade: conflitos e convivências nos espaços de diversão e prazer do Recife nos anos 1920. Tese (Doutorado em História). Universidade Federal de Pernambuco, Recife, 2003; MARINHO, Márcia Maria Fonseca. Natal também civiliza-se: sociabilidade, lazer e esporte na Belle Époque natalense (1900-1930). Dissertação (Mestrado em História). Natal: Universidade Federal do Rio Grande do Norte, 2008; SANTUCCI, Natália de Noronha. O elegante sport: conexões entre a moda, a modernidade e o ciclismo em Porto Alegre (1895-1905). Dissertação (Mestrado em História). Porto Alegre: Pontifícia Universidade Católica do Rio Grande do Sul, 2016; SILVA, Marcelo Moraes e. Novos modos de olhar, outras maneiras de se comportar: a emergência do dispositivo esportivo da cidade de Curitiba (1899-1919). Tese (Doutorado em Educação). Campinas: Universidade Estadual de Campinas, 2011. 
fatores a obliterar um aprofundamento teórico e interpretativo neste campo de pesquisas. ${ }^{4}$

Além disso, há também o predomínio do estudo de iniciativas associativas, que foram seguramente importantes para o início da difusão e oferta de um repertório de esportes. ${ }^{5}$ Todavia, afora o associativismo civil, espaços e práticas promovidas com caráter comercial desempenharam também um papel importante nesse processo. Como disse já Stephen Hardy ${ }^{6}$, a história social do esporte não constitui toda a história do esporte. Para além de questões culturais, que obviamente constituem esse fenômeno, há também aí dimensões de ordem financeira, econômica ou gerencial que devem igualmente ser levadas em conta. Esses tópicos, mais próximos de uma perspectiva econômica, exigem certo deslocamento da atenção do historiador especializado no estudo do esporte, usualmente confinado ao campo da história cultural. ${ }^{7}$ Ao lado da usual ênfase sobre o significado atribuído a prática ou ao consumo de esportes, portanto, o interesse deveria se expandir, nesse caso, em direção as estruturas de produção e de oferta comercial de espetáculos.

Desde longa data, empresários ou comerciantes estiveram entre alguns dos principais agentes de difusão de esportes. ${ }^{8}$ No Brasil, em particular, entre os anos finais do século 19 e as duas ou três primeiras décadas do século 20, em ambiente muito marcado por consumo conspícuo, em que grupos de elite tentavam utilizar espetáculos esportivos como forma de exibir publicamente seus status, seu poder econômico e seus pertencimentos a um universo de referências imaginado como civilizado e moderno, clubes esportivos tendiam a constituir círculos especialmente fechados, enquanto os espaços comerciais para a oferta e o consumo de espetáculos esportivos, de outro modo, motivadas pelo próprio princípio da busca de lucro, tendiam a ser mais tolerantes e inclusivos com grupos populares - embora mecanismos de exclusão e distinção também operassem ali, tanto quanto possibilidades de inclusão de grupos mais heterogêneos também existissem em clubes e associações. Em

${ }^{4}$ DIAS, Cleber. Esportes nos confins da civilização: Goiás e Mato Grosso, c. 1866-1937. Rio de Janeiro: 7 Letras, 2018.

${ }^{5}$ SZYMANSKI, Stefan. A Theory of the Evolution of Modern Sport. Journal of Sport History, v. 35, n. 1, p. $1-3,2008$.

${ }^{6}$ HARDY, Stephen. Entrepreneurs, Organizations, and the Sport Marketplace: Subjects in Search of Historians. Journal of Sport History, v. 13, n. 1, 1986.

${ }^{7} \mathrm{cf}$. PORTER, Dilwyn; VANPLEW, Wray. Entrepreneurship, Sport, and History: an Overview. The International Journal of the History of Sport, v. 35, Issue 7-8, p. 626-640, 2018; MELO, Victor Andrade de. Esporte e lazer: conceitos. Rio de Janeiro: Apicuri, 2010.

${ }^{8}$ PORTER, Dilwyn. Entrepreurship. In: POPE, S. W.; NAURIGHT, John (eds.). Routledge Companion to Sports History. New York / London: Routledge, 2010, p. 197-215. 
todo caso, empresários estiveram entre um dos primeiros e principais grupos responsáveis pela expansão de oportunidades de consumo de serviços tais como os espetáculos esportivos.

Diante desse contexto historiográfico, o artigo analisa a história das primeiras iniciativas para organização de corridas de bicicletas em Manaus, que aconteceram na transição entre os séculos 19 e 20. Iniciativas para organização de corridas de bicicletas em Manaus nesse período, que foi um dos primeiros esportes a se organizar na cidade, estiveram desde o início motivadas por interesses comerciais. Em Manaus, quase não houve a prática de corridas de bicicletas sem interseções com a organização de espaços e eventos que claramente buscassem o lucro. Em tais circunstâncias, seria inadequado analisar a história do ciclismo em Manaus desprezando o papel desempenhado por prerrogativas econômicas, tanto quanto seria inadequado estudar historicamente as primeiras iniciativas para organizar práticas esportivas ali sem levar em consideração o ciclismo. Nesses termos, quaisquer oposições teóricas entre economia e cultura, ou economia e esporte, para sermos mais específicos, devem desde logo ser relativizadas, pois o esforço para a construção de espaços para a prática e o consumo de esportes poderia ser motivado simultaneamente por várias razões, combinando o desejo de exibição pública de status com a busca de lucros ou outras vantagens econômicas indiretas, decorrentes das possíveis redes de contatos que poderiam ser construídas ou reforçadas durante os descontraídos encontros sociais que espetáculos esportivos oportunizavam - para não mencionar, obviamente, o prazer e a diversão propriamente ditos.

\section{Esportes em Manaus na transição entre os séculos 19 e 20}

O período em que acontecem as primeiras corridas de bicicleta em Manaus, a partir dos últimos anos do século 19, coincide com o apogeu das atividades de extração e exportação de borracha na região. A história desse período não apenas em Manaus, mas em toda a região da bacia amazônica, estaria, desde então, grandemente vinculada aos efeitos sociais, culturais e econômicos da produção de borracha para o mercado internacional. Entre 1852 e 1900, o crescimento do volume de exportação de borracha em toda a bacia amazônica, a partir dos portos de Belém e de Manaus, foi da ordem de 2.400\%. No período entre 1900 e 1910, cerca de $28 \%$ de todas as exportações brasileiras estavam ligadas ao mercado da borracha, perdendo em importância 
apenas para o café. Em 1912, a produção de borracha no Brasil atingiria seu maior volume histórico, nunca mais superado, de mais de 42 mil toneladas. ${ }^{9}$

$\mathrm{O}$ aumento da demanda na Europa e nos Estados Unidos provocado pela produção industrial em larga escala de novos produtos feitos agora com borracha é o grande responsável pela crescente exploração desta matéria-prima extraída de uma planta nativa da Amazônia. Ao lado do ferro, do aço e do petróleo, a borracha estava entre uma das mais importantes matérias-primas para a crescente produção industrial a partir da segunda metade do século 19. Tratava-se de um material versátil usado na produção de casacos, capacetes, botões, cintos, sapatos, suspensórios, capas de chuva, válvulas, mangueiras, telhas, seringas, correias de transmissão, amortecedores de vagões ferroviários e ainda utensílios domésticos diversos, entre várias outras coisas. A produção industrial de tantos itens aumentou progressivamente a demanda por borracha da Amazônia a partir das décadas de 1840 e 1850. No entanto, foi a necessidade de borracha para fabricação de pneus para bicicleta na Europa e nos Estados Unidos a partir de 1890 que ofereceu o primeiro grande impulso para a produção desta matéria-prima na região. ${ }^{10}$

O número de bicicletas fabricadas e vendidas nos Estados Unidos e em partes da Europa Ocidental cresceu muito a partir da última década do século 19. Na França, onde esteve situada uma das primeiras vanguardas tecnológicas desta indústria, estima-se que havia 300 mil bicicletas em 1898 e mais de 9 milhões em 1938. ${ }^{11}$ Nos Estados Unidos, no mesmo sentido, onde modelos e tecnologias foram importados ou simplesmente roubados da França antes de novos métodos de produção, distribuição e vendas terem sido de fato criados, estima-se que havia cerca de 150 mil ciclistas em 1890. Em 1896, falava-se já de 4 milhões, o que representaria um impressionante crescimento de mais de $2.500 \%$ de praticantes em apenas seis anos, dando origem ao que se chamou de "mania americana por ciclismo". ${ }^{12}$ Causa e consequência do abrupto crescimento do interesse pelo ciclismo, o número de fábricas de bicicletas nos Estados Unidos saltou de 6 em 1885, para 700 em 1896. ${ }^{13}$ Também na Inglaterra

\footnotetext{
${ }^{9}$ PRADO, Maria Lígia Coelho; CAPPELATO, Maria Helena Rolim. A borracha na economia brasileira da Primeira República. In: HOLANDA, Sergio Buarque de (dir.). História geral da civilização brasileira, tomo III, vol. 1, 8. ed. Rio de Janeiro, Bertrand Brasil, 1989, p. 287-307.

${ }^{10}$ WEINSTEIN, Barbara. A borracha na Amazônia: expansão e decadência, 1850-1920. São Paulo: Hucitec / Edusp, 1993, p. 23.

${ }^{11}$ HOLT, Richard. Sport and Society in Modern France. New York: Routledge, 1981.

${ }^{12}$ HARMOND, Richard. Progress and Flight: An Interpretation of the American Cycle Craze of the 1890s. Journal of Social History, n. 5, p. 235-257, 1971 (p. 240).

${ }^{13}$ RITCHIE, Andrew. The Origins of Bicycle Racing in England: Technology, Entertainment, Sponsorship, and
} 
cresceu ao longo do último quarto do século 19 o número de ciclistas, de competições, de clubes e de fábricas de bicicletas. Em 1898 havia mais de 50 mil sócios registrados nos mais de 740 clubes de ciclismo da Inglaterra. O número de fabricantes de bicicletas na Inglaterra em 1896 e 1897 ultrapassava os 800. ${ }^{14}$

Uma série articulada de amplas transformações tornou possível essa rápida expansão do mercado consumidor para bicicletas. Além de inovações tecnológicas na bicicleta em si, que tornaram o equipamento mais leve, confortável e fácil de guiar, ampliando, assim, o interesse de um público potencialmente maior, outros fatores sociais mais gerais também desempenharam papel importante nesse processo. Destaque-se o barateamento do transporte de mercadorias (que era em alguma medida transferido para o preço final dos produtos), o sistema de vendas a crédito e com preços fixos, o mercado de produtos usados, a paulatina popularização de produtos e serviços até então vistos como luxos (como viagens, compra de jornais ou a própria posse de bicicletas) e especialmente a elevação gradual dos salários e a progressiva redução da jornada de trabalho. Entre 1890 e 1950, o PIB per capita de vários países da Europa Ocidental quase dobrou. Ao mesmo tempo, a duração média das jornadas de trabalho diminuiu em mais de $50 \% .{ }^{15}$ Tudo isso, em suma, permitiu o florescimento de uma inédita demanda por vários itens para o consumo no lazer, incluindo aí a bicicleta.

Em resposta a essas transformações, fábricas dos Estados Unidos começaram a registrar superprodução de bicicletas em meados de 1890, logo inundando tanto o mercado norte-americano quanto o europeu, tornando então inevitável a diminuição dos preços. Apenas entre os anos de 1898 e 1901, estima-se que que cerca de 4 milhões de bicicletas tenham sido fabricadas somente nos Estados Unidos. ${ }^{16}$ Havia ainda a produção das fábricas da Inglaterra, da França e de alguns outros países da Europa. Boa parte da borracha utilizada nos pneus desses milhares de novas bicicletas era fornecida pelas árvores da floresta brasileira. Em 1900, estima-se que o Brasil era responsável pelo fornecimento de $95 \%$ de toda borracha consumida no mercado mundial. ${ }^{17}$

Advertising in the Early History of the Sport. Journal of Sports History, v. 26, n. 3, p. 489-520, Fall 1999 (p. 294). ${ }^{14}$ RITCHIE, Andrew. Early Bicycles and the Quest for Speed: A History, 1868-1903. 2 ed. Jefferson: McFarland \& Company, 2018, p. 303-360.

${ }^{15}$ MIGNOT, Jean-François. The History of Professional Road Cycling. In: Daam Van Reeth e Daniel Joseph Larson (eds.). The economics of professional road cycling. New York: Springer, 2016, p. 7-32.

${ }^{16}$ SMETHURST, Paul. The bicycle: towards a global history. London / New York: Palgrave Macmillan, 2015 (p. 21).

${ }^{17}$ JACKSON, Joe. O ladrão no fim do mundo: como um inglês roubou 70 mil sementes de seringueira e acabou com o monopólio do Brasil sobre a borracha. Rio de Janeiro: Objetiva, 2008. 
A partir de 1910, aproximadamente, a demanda gerada pela crescente produção de pneus para automóveis intensificou o processo de extração de borracha no Brasil. Foi o segundo grande impulso para a extração de borracha na Amazônia brasileira. Em 1914, apenas as fábricas de automóveis em Detroit, nos Estados Unidos, consumiram quase 2 milhões de pneus. Havia ainda os pneus necessários para os carros fabricados na Europa (em fábricas que muitas vezes antes produziam bicicletas). Precisamente nessa época, contudo, a produção brasileira perdeu mercado para produtores da Ásia, onde a planta nativa das florestas amazônicas que gera a seiva capaz de produzir a borracha foi aclimatada com sucesso por meio do contrabando de sementes promovido por ingleses. 0 contrabando de 70 mil sementes desta planta amazônica foi classificado já como "um dos atos de maior repercussão e sucesso de pirataria biológica da história mundial". ${ }^{18}$

Plantações da Ásia tinham um sistema de produção muito mais eficiente que o brasileiro, o que permitiu aumentar o volume de borracha extraído das plantas. A abundância de oferta de borracha, todavia, deprimiu os preços internacionais do produto por volta de 1910, diminuindo sua margem de lucro. Em princípios da década de 1920, o governo britânico, que controlava diretamente os seringais asiáticos que agora produziam parte significativa da borracha consumida no mercado internacional, iniciaram uma política de controle de produção, a fim de elevar o preço e a lucratividade desse negócio. A medida atingia diretamente fábricas norte-americanas, que consumiam entre 70 e $80 \%$ da borracha mundial ${ }^{19}$. 0 atendimento dessa demanda se tornou tão importante que Henry Ford, proprietário da famosa fábrica de veículos norte-americana, chegou a construir uma cidade no interior do Pará (Fordlândia), com o propósito específico de tentar contornar problemas na oferta desta matéria-prima. ${ }^{20}$

Antes do contrabando de sementes amazônicas para a Ásia e da debacle do sistema brasileiro de produção de borracha, porém, a maior parte da demanda do mercado mundial deste produto era de fato atendida pelo Brasil. Com efeito, o Brasil tinha o monopólio da produção deste produto até por volta de 1910. O dinamismo econômico gerado pelas atividades de extração e comercialização internacional desta matéria-prima nos seus períodos prósperos teve efeitos sobre uma série de aspectos da vida social da região

\footnotetext{
${ }^{18}$ Jackson, op. cit., s/p.

${ }^{19}$ Jackson, op. cit.

${ }^{20}$ GRANDI, Greg. Fordlandia: The Rise and Fall of Henry Ford's Forgotten Jungle City. New York: Metropolitan Books, 2009.
} 
amazônica, desde o crescimento demográfico até um pequeno estímulo aos mercados urbanos de entretenimento. A população de Manaus e Belém, as duas maiores cidades da região, cresceram cerca de $178 \%$ entre 1872 e 1910. No curto espaço de 20 anos, portanto, entre 1890 e 1910, Belém quase triplicou o tamanho de sua população, que saltou de 50 mil pessoas em 1890, para pouco mais de 96 mil em 1900, até atingir 190 mil em 1910. Em Manaus, de maneira menos drástica, mas também acelerada, a população da cidade quase dobrou de tamanho nesse período, saindo de 38 mil pessoas em 1890 para 50 mil em 1900, atingindo $64 \mathrm{mil} \mathrm{em} \mathrm{1910.}{ }^{21}$

O mercado de produção e exportação de borracha também aproximou comerciantes que atuavam na Amazônia brasileira dos fluxos da economia mundial. Contatos com comerciantes, industriais e financistas de outros países se tornaram cada vez mais frequentes na região. Capitalistas ingleses ampliaram sua presença no mercado da Amazônia brasileira, especialmente em Manaus e Belém. O comércio de exportação de borracha, importação de manufaturas e oferta de serviços urbanos nessas duas cidades eram em grande medida controlados por investidores ingleses. Não por acaso, era de origem inglesa o único banco estrangeiro que atuara em Manaus nesse período. A França, por outro lado, era o principal fornecedor de artigos de luxo, como roupas, sapatos, perfumes, vinhos e champanhes. Em 1904, por exemplo, a biblioteca da sede do Sport-Club do Pará, em Belém, dispunha da assinatura de 27 periódicos; a maioria da França e da Inglaterra. ${ }^{22}$ Na prática, portanto, a região se tornou comercialmente dependente da Inglaterra e culturalmente dependente da França. ${ }^{23}$

Fortunas foram geradas nesse processo de exportar borracha e importar produtos manufaturados. Nessa época, dizia-se que em Manaus e em Belém lavava-se roupas em lavanderias de Paris e acendia-se charutos com notas de dólar - em dizeres que tentavam ostentar a riqueza obtida com a produção e comercialização da borracha. De fato, a nova riqueza foi ostensivamente exibida pelas elites locais, que queriam se diferenciar das classes populares compostas por uma população crescente, ao mesmo tempo em que competiam por prestígio com elites de outros centros urbanos brasileiros. Exibir-se para visitantes estrangeiros como civilizados e em sintonia com os costumes de países considerados mais modernos também fazia parte das motivações para

\footnotetext{
${ }^{21}$ Weinstein, op. cit.

${ }^{22}$ DIAS, Cleber. Esporte e cidade: balanços e perspectivas. Tempo, v. 17, n. 34, p. 33-44, jun. 2013 (p. 40).

${ }^{23}$ BURNS, E. Bradford. Manaus, 1910: Portrait of a Boom Town. Journal of Inter-American Studies, v. 7, n. 3, p. 400-421, Jul. 1965 , p. 404.
} 
a assimilação de vários símbolos e práticas culturais, entre as quais, os esportes. A abolição da escravidão no Brasil em 1888 e a proclamação da república em 1889, quando todos os cidadãos foram formalmente considerados iguais perante a lei, apenas acentuou nas elites expectativas de exibir publicamente a riqueza como uma forma de distinguir-se da massa de pobres e miseráveis. ${ }^{24}$

Aproveitando a nova disponibilidade financeira, reformas urbanas foram empreendidas tanto em Manaus quanto em Belém: pontes foram construídas, ruas foram calçadas, portos foram ampliados, mercados foram reformados, praças foram ajardinadas, transportes foram aprimorados, sistemas de abastecimento de água e eletricidade foram inaugurados. Em Manaus, mudanças na legislação tornaram obrigatório o beneficiamento da borracha extraída na região antes da exportação. A medida buscava favorecer o porto de Manaus como ponto de exportação da produção, em detrimento do porto de Belém, visando favorecer a arrecadação tributária. ${ }^{25}$ Tentar assegurar recursos fiscais para o poder público era fundamental para viabilizar obras de embelezamento e modernização urbana da cidade. Impostos da exportação de borracha apareciam como a principal fonte de recursos nesse sentido. No final da década de 1910, cerca de $80 \%$ da arrecadação de impostos em Manaus vinha do comércio da borracha. ${ }^{26} \mathrm{Em}$ geral, essas reformas se concentraram em obras suntuosas e na construção de espaços destinados a sociabilidade dos ricos. ${ }^{27}$ Em Manaus, uma das obras mais emblemáticas nesse sentido foi a construção de um luxuoso teatro de ópera com recursos do poder público local, inaugurado em 1896, a um custo estimado de aproximadamente dois milhões de dólares. ${ }^{28}$ As obras foram executadas por uma empresa italiana, usando material importado da Inglaterra. ${ }^{29} \mathrm{~A}$ própria ênfase na época sobre a presença de italianos e ingleses no processo de construção do teatro já denuncia o apelo simbólico que referências europeias desempenhavam sobre grupos da elite local. A presunção simbólica desses grupos era tão grande que começou a circular a partir dessa época a noção de que Manaus era a "Paris

\footnotetext{
${ }^{24}$ COSTA, Emília Viotti da. Da monarquia à república: momentos decisivos. 6 ed. São Paulo: Fundação Editora da UNESP, 1999.

${ }^{25} \mathrm{DAOU}$, Ana Maria. A cidade, o teatro e o "paiz das seringueiras": prática e representações da sociedade amazonense na passagem do século XIX-XX. Rio de Janeiro: Rio Books, 2014.

${ }^{26}$ Burns, op. cit.

${ }^{27}$ DIAS, Edinea Mascarenhas. A ilusão do fausto: Manaus, 1890-1920. Manaus: Valer, 1999.

${ }^{28}$ Burns, op. cit.

${ }^{29}$ Daou, op. cit.
} 
das selvas": uma cidade encravada no coração da floresta amazônica, mas com todas as amenidades de um grande centro urbano europeu.

Nesse contexto, mais de 30 clubes esportivos dedicados a diferentes modalidades foram criados em Manaus entre os últimos anos do século $19 \mathrm{e}$ o final da primeira década do século 20. Esgrima, críquete, tênis, remo, turfe, ciclismo e futebol estiveram entre as modalidades praticadas nesses clubes. ${ }^{30} \mathrm{O}$ perfil geral dos sócios de tais associações parecia semelhante. Tal como ocorreu em várias partes do Brasil, o início da organização de práticas esportivas em Manaus esteve ligado a grupos das elites ou dos estratos médios superiores, tais como médicos, juízes, advogados, comerciantes ou oficiais militares. Além disso, esse universo era constituído por uma rede de sociabilidade relativamente restrita. Às vezes as mesmas pessoas estiveram envolvidas na fundação de mais de um clube esportivo. Em Manaus, por exemplo, Deodoro Freire, José Maranhão e Raymundo B. Britto Pereira, pouco depois de participarem, em 1906, da fundação de uma associação chamada "Club Desportivo", estariam também envolvidos na organização de corridas de bicicleta na cidade, como logo veremos. ${ }^{31} \mathrm{O}$ ativo José Maranhão, aliás, também estaria envolvido pouco depois com a construção de um hipódromo para corridas de cavalos, como também comentaremos brevemente adiante.

A participação ou mesmo o consumo de espetáculos esportivos parecia tentar suprir expectativas simbólicas de exibição de status através da intensificação das interações sociais nos espaços públicos. Tratava-se, em última instância, de mais um recurso para exibição de riqueza econômica, bem como de afinidade cultural com as elites de outros centros urbanos tidos como mais modernos e civilizados, especialmente grandes cidades da Europa, como Paris ou Londres. Campos de esportes e espaços de sociabilidade a eles relacionados, como bailes e festas nas sedes sociais dos clubes esportivos, funcionavam como a materialização de aspirações de cosmopolitismo que afetavam certos grupos do país, compondo parte do cenário que pretendia dramatizar uma nova sociedade moderna e em vertiginoso progresso..$^{32}$

Foi precisamente nesses termos que o esporte foi inicialmente difundido em Manaus. Tal como aconteceu em muitas cidades do Brasil, jornais de Manaus noticiavam eventos esportivos usando termos em inglês, exibindo

\footnotetext{
${ }^{30}$ SOUZA, Eliza Salgado de. Panorama do esporte em Manaus, 1897-1911. Dissertação (Mestrado em Estudos do Lazer). Belo Horizonte: Universidade Federal de Minas Gerais, 2017.

${ }^{31}$ Club desportivo. Jornal do Commercio, Manaus 21 maio. 1906, n. 680, p. 1.

${ }^{32} \mathrm{cf}$. NEEDELL, Jeffrey D. Belle époque tropical: sociedade e cultura de elite no Rio de Janeiro na virada do século. São Paulo: Companhia das Letras, 1993.
} 
familiaridade com aquelas práticas e tornando-as ainda mais distantes do conjunto da população - que já estava em grande medida excluído daquele universo pelo analfabetismo, pela relativa indisponibilidade financeira para comprar jornais e pela obstrução dos canais de acesso as associações promotoras de esportes. Nesse sentido, os clubes de esportes seriam, ou deveriam ser, de acordo com o sistema de crenças que animava seus primeiros adeptos, mais uma demonstração de que a modernidade, afinal, havia chegado em Manaus. Mais que isso, a fundação de clubes esportivos e a realização de competições também indicava que seus sócios (fossem praticantes ou apenas espectadores), não apenas estavam atualizados com o que acontecia em outras cidades, como ainda tomavam parte diretamente dessas transformações - sempre representadas como desejáveis e até necessárias.

Essas expectativas estavam presentes não apenas em associações civis (clubes), mas também em espaços dedicados a oferta comercial de oportunidades para o consumo de espetáculos esportivos. A oferta regular e se possível abundante de oportunidades de lazer comercial também era visto como elemento indispensável para uma cidade que se pretendia moderna, civilizada e cosmopolita. ${ }^{33}$ Em várias dimensões do cotidiano, a introdução de mecanismos típicos de uma economia de mercado, especialmente a compra e venda de produtos e serviços em troca de pagamentos em dinheiro, era muitas vezes vista como elemento importante do processo de modernização das relações sociais. Isto representava uma significativa mudança de valores, pois até meados do século 19, aproximadamente, predominou no Brasil uma atitude de desconfiança com relação as atividades comerciais. Até aquele momento, prevalecia o entendimento de que o comércio, isto é, a atividade de intermediação entre o produtor e o comprador, era algo potencialmente perigoso ao bem comum, precisando, por isso, de ativa regulação do poder público, a fim de se evitar a atuação de vendedores inescrupulosos. Existia certa noção de que a ganância desmedida de vendedores e o desejo excessivo de lucros de comerciantes eram atividades suspeitas, pecaminosas até. ${ }^{34}$

Por volta dos meados do século 19, no entanto, como consequência de transformações materiais e ideológicas que se processavam desde os fins do século 18, tudo isso mudou, cedendo lugar a uma nova visão onde

\footnotetext{
${ }^{33}$ DIAS, Cleber; et. al. Esportes nos sertões das Gerais. In: DIAS, Cleber; ROSA, Maria Cristina (Orgs.). Histórias do lazer nas Gerais. Belo Horizonte: Editora da UFMG, 2019, p. 137-162.

${ }^{34}$ GRAHAM, Richard. Alimentar a cidade: das vendedoras de rua à reforma liberal (Salvador,1780-1860). São Paulo: Companhia das letras, 2013; MOURA, Denise A. Soares de. A sociedade movediça: economia, cultura e relações sociais em São Paulo: 1808-1850. São Paulo: Ed. da Unesp, 2005.
} 
paulatinamente passou a predominar a valorização do comércio e da busca do lucro. Daí em diante, a busca deliberada por vantagens econômicas individuais através do comércio de produtos e serviços diversos passou a ser não apenas aceita, como socialmente valorizada. Pouco a pouco, os domínios do comércio e do consumo generalizaram-se para todas as esferas da vida. A intensificação de atividades econômicas, com sua consequente geração de riquezas, associadas ao crescimento populacional, ao adensamento urbano em alguns centros e ainda as transformações no estatuto jurídico da cidadania a partir de 1888 e 1889, quando todos os indivíduos foram formalmente reconhecidos como livres e iguais, favorecerem a consolidação do consumo como uma esfera privilegiada de distinção social. ${ }^{35}$ As roupas utilizadas, o modo de se alimentar ou as formas de se divertir ampliaram suas funções sociais como indicadores públicos do grau de civilidade e respeitabilidade de um indivíduo. Nesse contexto, o comércio e o consumo, isto é, a venda e a compra de produtos e serviços em troca de dinheiro eram repetidamente apresentadas como sinais e instrumentos de progresso. Restaurantes, cervejarias, charutarias, bilhares, cafés, bares, lojas e clubes sociais ou recreativos logo se tornaram espaços privilegiados para concretização desses ideais.

No universo dos lazeres, artigos de jornais inúmeras vezes enfatizaram que uma cidade que pretendesse ser moderna e civilizada deveria oferecer aos seus cidadãos oportunidades frequentes de consumo de certas práticas, tais como espetáculos de teatro, exibição de filmes em cinemas ou espetáculos esportivos. ${ }^{36}$ Todavia, além do implícito desejo de consumo conspícuo que palavras desse tipo iam deixando ver, interesses políticos e financeiros também perpassavam tais práticas. Clubes esportivos ou tribunas de honras de estádios, bem como sacadas de teatros e salões sociais de associações recreativas, eram, afinal, lugares onde se teciam relações e onde se podia estreitar contatos com possíveis novos parceiros comerciais ou potenciais apoiadores políticos, além de oferecerem também oportunidades de lucros e ganhos financeiros para quem administrasse tais espaços.

Nesses termos, é quase impossível separar inteiramente o quanto as motivações na oferta ou no consumo dessas práticas eram econômicas, políticas, sociais ou recreativas. Todas essas motivações pareciam estar simultaneamente presentes no ato de consumir espetáculos esportivos ou outros

\footnotetext{
${ }^{35}$ OLIVEIRA, Milena Fernandes de. Cultura de consumo e indústria na São Paulo da belle époque (18901915). História econômica \& história de empresas, v. 17, n. 1, p. 177-208, 2014.

${ }^{36}$ Dias, et.al., op. cit.
} 
gêneros de diversão pública. É nesse sentido, portanto, que economia e cultura aparecem como elementos complementares e não antagônicos.

\section{Grupo Ciclista Amazonense e o Velódromo Nacional}

Em 1898 foi criado o Grupo Ciclista Amazonense, que a partir de então organizou passeios e corridas de bicicletas em Manaus. ${ }^{37}$ Seu presidente era Joaquim da Costa Soares, comerciante português, tesoureiro da Sociedade Beneficente Portuguesa e proprietário da Casa Havaneza, uma loja que vendia produtos variados. ${ }^{38}$

Meses antes da criação do Grupo Ciclista Amazonense, o entusiasmo pioneiro de Joaquim da Costa Soares pelo ciclismo causou espanto entre alguns setores da sociedade de Manaus. Em junho de 1898, Costa Soares foi repreendido por policiais por andar de bicicleta pelas ruas da cidade com trajes que deixavam parte de suas pernas à mostra, o que lhes parecia então ofender a moralidade. Segundo noticiou o jornal Commerio do Amazonas, Costa Soares teria sido interpelado por essas autoridades policiais na ocasião, que lhe impuseram as opções de mudar as roupas ou sair das ruas: "ou veste meias altas ou recolhe-se a casa", teriam dito. Ao final, optou por recolher-se à casa. Ao noticiar o episódio, porém, o jornal citava a Inglaterra, a França e a Alemanha, onde seria comum, conforme destacou-se, passear de bicicletas usando trajes "elegantes", "simples" e "cômodos". ${ }^{39}$ Já no dia seguinte, em decisão que manifestava sua concordância sobre o caráter elegante e civilizado do novo costume, o chefe de segurança da cidade declarou que iria "mandar baixar as ordens competentes aos seus subalternos afim de que estes não tornem, como arroubos de moralidade, a impedir os ciclistas". ${ }^{40}$

O episódio releva o estranhamento que setores provavelmente amplos daquela sociedade tinham ainda com costumes que eram anunciados, sobretudo por integrantes da elite local, como modernos, cosmopolitas e civilizados. Policiais, que usualmente provinham de estratos mais populares, olhavam com suspeitas para os novos hábitos. O episódio deixa ver também que a identificação com tais práticas operava como um signo de pertencimento de classe, dado que a posse de uma bicicleta e a adesão ao ciclismo era ainda restrita a pequenos grupos da elite local. Nessa época, mesmo na Europa e

\footnotetext{
${ }^{37}$ Grupo Cyclista Amazonense. Commercio do Amazonas, Manaus, 20 de novembro de 1898, n. 332, p. 2.

${ }^{38}$ Declaração. Diario Official, Manaus 1 de novembro de 1896, n. 845, p. 4; Beneficente Portuguesa. Commercio do Amazonas, Manaus, 1 de dezembro de 1900, n. 111, p. 1.

${ }^{39}$ Commercio do Amazonas, Manaus, 12 de junho de 1898, n.230, p. 1.

${ }^{40}$ Commercio do Amazonas, Manaus, 13 de julho de 1898, n. 231, p. 1
} 
nos Estados Unidos, onde ocorria progressivo aumento de salários, acompanhado por simultânea redução dos preços das bicicletas, graças aos novos processos de distribuição, comercialização e produção industrial em larga escala, tais equipamentos ainda eram artigos de luxo, disponíveis a grupos relativamente privilegiados, especialmente estratos intermediários e a elite da classe trabalhadora. Em Paris, por exemplo, por volta de 1893, uma bicicleta custava o equivalente a 1.655 horas de trabalho de um operário. ${ }^{41}$ No Brasil, a esses valores eram acrescidas ainda taxas de alfândega e outros custos de importação. ${ }^{42}$ Com o tempo, porém, pouco a pouco o ciclismo e as bicicletas ganhariam maior presença e visibilidade no cotidiano de cidades brasileiras, tal como aconteceu também na Europa e nos Estados Unidos.

O primeiro indício documental sobre uma corrida organizada pelo Grupo Cyclista Amazonense data de julho de 1898. Tratou-se de uma corrida com 7 páreos, realizada numa construção especialmente edificada para esse fim, na Praça General Osório, que seria conhecido então como "Velódromo Nacional". ${ }^{43}$ Nada sabemos sobre o processo de construção dessas instalações. Quanto tempo levou para ser edificado? Teria sido uma construção provisória para algum período de festividade? Contou com recursos de particulares, com apoio do poder público ou ambos? Cobrava-se ingressos? Vendia-se bilhetes de apostas? Ao que parece, havia um coreto e uma pista de 250 metros de extensão.

A estrutura geral das corridas organizadas ali seguiu um padrão bem estabelecido. Corredores se inscreviam em lojas da cidade que apoiavam o evento por meio da oferta de prêmios aos vencedores de cada páreo. Essas lojas também expunham esses prêmios nos dias que antecediam as corridas como forma de divulga-las e tentar mobilizar mais pessoas para o evento, além de aproveitar a ocasião para divulgar a própria loja. Os prêmios poderiam ser perfumes, álbuns para retratos, estojos para barba ou ainda medalhas, chapéus, bengalas, abotoadoras, canetas e alfinetes de ouro. ${ }^{44}$ Os proprietários das lojas implicadas nessas corridas geralmente também estiveram envolvidos mais diretamente com as atividades propriamente ditas do Grupo Ciclista no velódromo. A joalheria Porta Larga, por exemplo, que diversas vezes ofereceu e exibiu alguns dos prêmios que seriam dedicados aos vencedores de corridas, era de propriedade de José Joaquim Pinto de França, ciclista que participava

\footnotetext{
${ }^{41}$ HOLT, Richard. Sport and Society in Modern France. New York: Routledge, 1981.

${ }^{42}$ Gambeta, op. cit.; Schetino, op. cit.

${ }^{43}$ Commercio do Amazonas, Manaus, 26 de julho de 1898, n. 241, p. 1.

${ }^{44} \mathrm{O}$ Grupo Cyclistico Amazonense. A Federação, Manaus, 06 de dezembro de 1898, n. 274, p. 1.
} 
dos páreos no Velódromo Nacional de Manaus nessa época, chegando a obter certa notoriedade na cidade como "sportman", que era a maneira como se chamavam os praticantes de esportes no período. Do mesmo modo, a Livraria Clássica, onde se fizeram inscrições para algumas corridas, era de propriedade de Jayme do Canto Albuquerque e Joaquim Jacintho da Camara, que atuaram, ambos, como juízes de partidas em corridas no Velódromo Nacional de Manaus. ${ }^{45}$

A estrutura organizacional dessas corridas contava com cinco diferentes categorias de juízes, que poderiam somar até 11 pessoas: um juiz de partida, um de confirmação, um de chegada, quatro de raia e quatro "cronômetros". O registro dos tempos de cada corrida procurava ser minucioso, anotando-se e divulgando-se minutos e segundos. Às vezes jornais davam destaque a precisão desta marcação de tempos. Pode parecer banal nos dias de hoje, mas este era um aspecto digno de registro para os padrões da época. $O$ registro do tempo e das distâncias com tamanha precisão materializava toda uma nova sensibilidade com relação ao tempo e ao espaço. ${ }^{46}$

Corridas e passeios também eram realizadas nas ruas da cidade, embora tivessem frequência menor do que aquelas realizadas no velódromo, além de restringirem à participação apenas aos integrantes do clube, o que não era uma exigência formal nas corridas realizadas no velódromo e tendia a tornar ainda mais restritivo as oportunidades de acesso a este esporte, que já era presumivelmente reduzido por causa dos preços das bicicletas. ${ }^{47}$ A realização das corridas em um espaço público, contudo, permitia a participação de grupos mais amplos como espectadores.

Tal como aconteceu em vários outros lugares, os jornais desempenharam papel muito importante no desenvolvimento do interesse por esportes

\footnotetext{
${ }^{45}$ Ao commercio e as repartições públicas. Diario Official, Manaus, 19 de outubro de 1895, n. 551, p. 8; Ao commercio e as repartições públicas. Jornal do Commercios, Manaus, 23 de julho de 1904, n. 176, p. 3; Commercio do Amazonas, Manaus, 13 de dezembro de 1898, n. 347, p. 1; Segunda apparição à imprensa. A Federação, Manaus 25 de dezembro de 1898, n. 292, p. 2; Sociedade do tiro Brasileiro no Amazonas. Jornal do Commercio, Manaus, 12 de março de 1908, n. 1.424, p. 3; Velodromo Nacional. A Federação, Manaus 15 de novembro de 1898 , n. 253 , p. 2.

${ }^{46}$ Ritchie, 2018, op. cit.; CREAS, Robert. A medida do mundo: a busca por um sistema universal de pesos e medidas. Rio de Janeiro: Zahar, 2013; GUTTMANN, Allen. From Ritual to Record: the Nature of Modern Sports. Columbia University Press, 2004; VIGARELLO, Georges. Treinar. In: CORBIN, Alain; COURTINE, Jean-Jaques; VIGARELLO, Georges (dirs.). História do corpo, v. 3 (as mutações do olhar: o século XX). Petrópolis: Vozes, 2008, p. 197-251; VIGARELLO, Georges; HOLT, Richard. O corpo trabalhado - ginastas e esportistas no século XIX. In: CORBIN, Alain; COURTINE, Jean-Jaques; VIGARELLO, Georges (dirs.). História do corpo, v. 2 (da Revolução à Grande Guerra). Petrópolis: Vozes, 2008, p. 393-477.
}

${ }^{47}$ Commercio do Amazonas, Manaus, 8 de dezembro de 1899, n.84, p. 2. 
em Manaus. ${ }^{48}$ A imprensa procurava incentivar o ciclismo, elogiando, de modo geral, iniciativas do Grupo Ciclístico, dando-lhe publicidade, além de enfatizar a necessidade e a utilidade pública desse tipo de diversão, tomada como índice geral do grau de civilidade de um povo, conforme disseram mais de uma vez..$^{49}$ A divulgação das corridas nos jornais de Manaus geralmente implicava a publicação de chamadas para a inscrição e alguns detalhes do programa das corridas, tais como número de páreos e corredores, bem como dia, horário e local de saída, ou ainda os resultados das corridas. Afora o pagamento puro e simples de propagandas, o envolvimento de ciclistas com jornais da cidade era outro elemento que facilitava a divulgação de notícias sobre o novo esporte. Coriolano Durand, por exemplo, conhecido nas rodas esportivas de Manaus como Petit Breton (nessa época era comum que ciclistas usassem apelidos), atuava como juiz em diversas corridas do velódromo, ao mesmo tempo em que escrevia crônicas esportivas no Jornal do Commercio.

O modo como a imprensa local noticiou a maioria dessas corridas tendia a ser elogioso. Destacava-se a presença do público, usualmente descrito como "enorme" e "extraordinário", além de quase sempre imbuídos de "completa animação". ${ }^{50}$ A corrida realizada nas comemorações da proclamação da República, por exemplo, em novembro de 1898, teria contado com público de 5 mil pessoas, conforme notícias divulgadas pelo jornal A Federação. ${ }^{51}$ Os adjetivos e as estimativas dessas descrições devem ser vistos com suspeitas, dado a possibilidade, bastante provável, de se tratarem de propagandas, embora isto não seja claramente identificável.

A imprensa, além disso, eventualmente divulgava também acontecimentos esportivos de outras cidades do Brasil e da Europa, frequentemente mencionadas como "centros mais adiantados", no que era parte de um expediente de justificar a razão pela qual essas práticas deveriam ser assimiladas também em Manaus. Uma vez que os costumes de outras cidades do Brasil ou da Europa eram tomados como exemplos a serem seguidos, legitimava-se, assim, o esforço em dar continuidade a esses eventos, bem como justificava-se as reiteradas solicitações de apoio às iniciativas que os promoviam.

\footnotetext{
${ }^{48} \mathrm{cf}$. CARVALHO, John. Communications and Journalism. In: Robert Edelman and Wayne Wilson (eds.). The Oxford Handbook of Sports History. 2017; BUARQUE DE HOLLANDA, Bernardo Borges; MELO, Victor Andrade de. $O$ esporte na imprensa e a imprensa esportiva no Brasil. Rio de Janeiro: 7 Letras, 2012.

${ }^{49}$ Grupo Cyclista Amazonense. Commercio do Amazonas, Manaus 28 de julho de 1898, n. 243, p .1; Grupo Cyclista Amazonense. Commercio do Amazonas, Manaus, 22 de janeiro de 1899, n. 379, p. 2.

${ }^{50}$ A Federação, Manaus, 16 de novembro de 1898, n. 254, p. 1; Grupo Cyclista Amazonense. Commercio do Amazonas, Manaus, 3 de agosto de 1898, n. 248, p. 1.

${ }^{51} \mathrm{O}$ Grupo Cyclista Amazonense. A Federação, Manaus ,17 de novembro de 1898, n. 255, p. 1.
} 
Jornais viam a si mesmos como índices de civilização de uma cidade; um farol a guiar os costumes de um povo em tudo visto como bárbaro, inculto e incivilizado. Nesse sentido, mais do que apenas divulgar os acontecimentos, jornais tentavam também impor certos códigos de conduta através da divulgação de elogios ou reprimendas ao comportamento do público e dos esportistas no velódromo. De um lado, exaltavam o respeito e a disciplina do que julgavam e diziam ser os "distintos sportmen", ou seja, os membros da elite local que tomavam parte das corridas de bicicleta, ao mesmo tempo em que censuravam, de outro lado, o que classificavam como "excessos de entusiasmo de uma parte dos espectadores", vistos, afinal, como descorteses por vaiarem os ciclistas derrotados nas corridas. ${ }^{52}$ Conforme uma crítica desse tipo publicada no jornal A Federação, "o povo amazonense encontra encantos nesse divertimento, e os dignos ciclistas que o promovem merecem um pouquinho mais de delicadeza da parte de uns tantos grupos que se exageram nas manifestações de entusiasmo". ${ }^{3}$

Não sabemos ao certo o que aconteceu com o Velódromo e com o Grupo Cyclista Amazonense a partir de 1900. A série documental dos periódicos de Manaus do acervo da Biblioteca Nacional do Rio de Janeiro, que constituem as principais fontes dessa pesquisa, é incompleta para esse período. Faltam edições dos jornais justamente entre os anos 1900 e 1904. A partir de 1904, quando jornais publicados em Manaus voltam a ter edições preservadas e disponíveis no acervo da Biblioteca Nacional do Rio de Janeiro, o Velódromo e o Grupo Cyclista Amazonense estão ausentes das notícias. Isto sugere que o local já não estivesse em atividade nesse período, embora ausência de evidências não signifique necessariamente evidência de ausência, pois teria sido possível que competições de corridas de bicicletas tivessem sido organizadas sem que os jornais as noticiassem, ou ainda que competições desse tipo tivessem acontecido e os jornais as tivessem registrado, sem que nenhuma edição desses jornais tivesse sido preservada. A partir das fontes disponíveis nesse acervo em particular, é impossível saber com certeza. Não obstante, a partir dessas mesmas fontes, parece razoável supor que esse velódromo tenha sido desativado em algum momento entre 1900 e 1903 ou 1904. Reforçando a hipótese, a partir de 1905, inicia-se a construção de um novo velódromo, já em outro ponto da cidade. Nessa época, Manaus não possuía um mercado consumidor grande o suficiente para viabilizar o funcionamento simultâneo

\footnotetext{
${ }^{52}$ Commercio do Amazonas, Manaus, 26 de julho de 1898, n. 241, p. 1.

${ }^{53}$ O Grupo Cyclistico Amazonense. A Federação, Manaus, 6 de dezembro de 1898, n. 274, p. 1.
} 
de dois velódromos - como o próprio destino deste segundo velódromo de certo modo demonstraria.

\section{Velódromo Amazonense}

O "Velódromo Amazonense", como ficou mais conhecida a construção, por vezes também chamado "Velódromo da Manaus Sport" ou "Velódromo da Cachoeirinha”, estava situado na Praça Visconde do Rio Branco, no bairro da Cachoeirinha, donde decorre um dos nomes pelos quais o local era reconhecido. Já o nome "Velódromo da Manaus Sport" fazia referência a instituição que administrava o local: "Manaus Sport", uma empresa constituída especialmente para administrar as corridas de bicicleta realizadas nesta instalação.

Construído a partir de 1904 por meio de uma associação comercial entre os empresários José de Albuquerque Maranhão e José Cardoso Ramalho Junior, que fundaram uma empresa de nome "Maranhão \& Cia", o "Velódromo Amazonense" foi inaugurado no ano seguinte, após algumas previsões frustradas de inauguração. ${ }^{54}$

O pernambucano José Albuquerque Maranhão era um empresário envolvido com diversos negócios em Manaus. Era proprietário de um prédio, empreiteiro de obras públicas e sócio de contratos para venda de carnes na cidade. Seu cunhado e sócio no velódromo, José Cardoso Ramalho Junior, nascido no Amazonas e que fizera parte de sua formação escolar em Portugal, também era comerciante e anos depois entraria também na política, onde exerceria os cargos de deputado federal, vice-governador e governador do Amazonas. $^{55}$

A pista do velódromo, provavelmente de terra e oval, com 333 metros de comprimento, contava com duas entradas (uma ao lado da rua Municipal, outra na rua Duque de Caxias). Uma das entradas (da rua Duque de Caxias) era conhecida como "popular", sugerindo que a outra (da Rua Municipal), era destinada a estratos superiores..$^{56} \mathrm{~A}$ partir de 1906 , haveria cinco diferentes categorias de preços dos ingressos.

\footnotetext{
${ }^{54}$ Jornal do Commercio, Manaus, 28 de dezembro de 1904, n. 316, p. 1; Contra a moral. Correio do Norte, Manaus, 3 de março de 1906, n. 36, p. 1; Sport. Jornal do Commercio, Manaus, 30 de setembro de 1904, n. 236, p. 1; Jornal do Commercio, Manaus, 8 de janeiro de 1905, n. 326, p. 2; Manáos-Sport. Jornal do Commercio, Manaus, 30 de outubro de 1904, n. 263, p. 1; Manaos Sport. Jornal do Commercio, Manaus, 19 de março de 1905, n. 386, p. 1; Velodromo. Jornal do Commercio, Manaus, 23 de dezembro de 1905, n. 626, p. 2.

${ }^{55}$ A defesa e a resposta ao repto. Quo Vadis, Manaus, 15 de maio de 1903, n. 146, p. 3; Superintendencia Municipal de Manáos. A Capital, Manaus, 20 de janeiro de 1918, n. 185, p. 3; Que Contraste. Correio do Norte, Manaus, 7 de abril de 1906, n. 66, p. 1.

${ }^{56}$ Velodromo Amazonense. Jornal do Commercio, Manaus, 3 de janeiro de 1907a, n. 905, p. 3.
} 
Entre o final de 1905 e princípios de 1906, pouco tempo depois de ter sido inaugurado, o velódromo já passou por reformas que teriam envolvido mais de 100 operários, indicando que se tratou de uma obra de vulto. A pista foi cimentada, coretos de alvenaria foram construídos, além da arquibancada ter sido embelezada. $O$ investimento pouquíssimo tempo depois da inauguração sugere que o negócio de organização de corridas de bicicleta em Manaus era visto como promissor.

Reivindicando pagamentos em atraso, operários realizaram duas greves durante as reformas do velódromo. Graças a greve, que chamou atenção de uma parte da imprensa local, sabemos que a praça onde foi construído o velódromo fora uma concessão do poder público e que o governo estadual, além disso, teria destinado recursos à reforma. ${ }^{57}$ Não conseguimos estabelecer mais detalhadamente as relações que teriam permitido ou justificado o envolvimento do poder público com essa reforma, que afinal beneficiava diretamente aos empresários que capitaneavam a iniciativa. Em todo caso, depois da reforma, uma nova e mais elaborada estrutura arquitetônica para o velódromo emergiu.

No período em que funcionou, o Velódromo Amazonense teve três diretores, que eram responsáveis pela organização geral das corridas. 0 primeiro deles foi o próprio José Maranhão Albuquerque. No período em que Maranhão Albuquerque dirigiu o velódromo, em 1905, antes das tais reformas, as corridas eram realizadas nas tardes de domingo, com quatro ou cinco páreos, cada um contando três, quatro, cinco ou seis ciclistas, em distâncias que variavam entre duas e 15 voltas na pista, somando, portanto, distâncias entre 600 e 10 mil metros.

Para tomar parte nas corridas, os ciclistas interessados deveriam se inscrever antecipadamente na sede da Manaus Sport (que nessa época ficava na Rua Deodoro, no centro de Manaus), o que exigia o pagamento de uma taxa, cujo valor não conseguimos apurar. Havia prêmios aos vencedores, mas apenas ao primeiro colocado (a partir de 1906 o segundo colocado seria também contemplado). Nesse momento, as corridas contavam cinco diferentes tipos de juízes, basicamente mantendo a mesma estrutura de organização adotada pelo outro velódromo que funcionou na cidade entre os últimos anos do século 19 e os princípios do século 20: o de partida, o de confirmação, o de raia,

${ }^{57}$ Contra a moral. Correio do Norte, Manaus, 3 de março de 1906, n. 36, p. 1; Contra a moral. Correio do Norte, Manaus, 6 de março de 1906, n. 38, p. 1. 
o de chegada e o de arquibancada. Algumas dessas funções envolviam mais de uma pessoa, somando, assim, um total de cerca de 11 juízes por corrida. ${ }^{58}$

Em 1906, pouco depois da reinauguração do velódromo, por conta das reformas já mencionadas, a direção do empreendimento ficou a cargo de Raymundo B. Britto Pereira, secretário da Manaus Sport, além de proprietário da loja Prato Chinês, que vendia louças e outros artigos variados na cidade. ${ }^{59}$ Nessa época, a loja de Britto Pereira passou a ser o local para inscrições nas corridas do velódromo, substituindo a sede da Manaus Sport, que era antes usada para esse fim, como vimos. Além disso, o número de páreos por corrida aumentou para seis ou sete. O número de juízes também aumentou. Além dos que já existiam antes, havia agora um juiz médico, um juiz telegrafista e cinco juízes "chronometers", totalizando, assim, 20 pessoas envolvidas em tais funções. Aumentou, portanto, a complexidade organizacional dos eventos realizados ali.

Outra mudança foi a introdução de diferentes tipos de disputa. Além das convencionais competições entre vários ciclistas que partiam de um mesmo ponto, acrescentou-se o "handicap", o "desafio", a "corrida parada", o "match" e o "match à trois". O "handicap" era uma corrida em que os competidores partiam de pontos diferentes. $O$ corredor que cedia aos outros uma determinada distância de vantagem era o "scratch", enquanto os demais eram chamados "limitman" - com os termos sempre apresentados em inglês nos jornais locais. Tais corridas envolviam apenas ciclistas ou também disputas entre ciclistas e corredores a pé. Já o "match" era o confronto direto entre dois ciclistas partindo do mesmo local e que deveriam percorrer a mesma distância. Quando confrontos desse tipo eram realizados em razão do desafio lançado por algum dos corredores, dava-se então o nome de "desafio". A variação envolvendo três ciclistas era o "match à trois". Finalmente, "corridas paradas" eram tentativas de se bater recordes de tempo em distâncias determinadas, em espécies de corridas contra o relógio.

Vários outros arranjos foram experimentados, com sucessos ou fracassos variados. Apareceram no velódromo de Manaus nessa época as "tandem”, que eram bicicletas para dois ciclistas. Organizaram-se então corridas entre "tandens" e bicicletas convencionais com apenas um ciclista. Houve também

\footnotetext{
${ }^{58}$ Manaos Sport. Jornal do Commercio, Manaus, 19 de fevereiro de 1905, n. 362, p. 1; Manaos Sport. Jornal do Commercio, Manaus, 19 de março de 1905, n. 386, p. 1; Velodromo. Jornal do Commercio, Manaus, 23 de dezembro de 1905, n. 626, p. 2.

${ }^{59}$ Prato Chines. Jornal do Commercio, Manaus, 26 de agosto de 1906, n. 777, p. 3; Jornal do Commercio, Manaus, 30 de março de 1905, n. 392, p. 2.
} 
competições entre ciclistas e corredores a pé. Logo realizaram-se competições envolvendo apenas corredores a pé, chamadas "perna contra perna". Corridas de velocípedes para crianças também tiveram lugar. ${ }^{60}$

Outra inovação que parece ter despertado interesse foi o uso de motocicletas, que ganharam destaque nos programas e na descrição dos páreos publicados em jornais da cidade. 0 primeiro a usar tal apetrecho no velódromo de Manaus foi Francisco Velosso, conhecido nas rodas esportivas da cidade pelo pseudônimo "Minerva" ${ }^{61} \mathrm{O}$ motociclista, nesse caso, assumia o papel de "treinador" (ou "entraineur", como se dizia na época), cuja função era ditar o ritmo para um dos ciclistas envolvidos na disputa, além de eventualmente dar-lhe orientação. Houve também tentativas de se realizar corridas em que cada ciclista contaria com um treinador em sua respectiva motocicleta. ${ }^{62} \mathrm{Ao}$ menos uma vez, houve ainda uma corrida entre duas motociclistas. ${ }^{63}$

Problemas mecânicos nas motocicletas e nas bicicletas tandens estiveram entre um dos principais motivos para críticas e para o relativo insucesso desses tipos de corrida. Por outras razões, competições entre ciclistas e corredores a pé, bem como entre ciclistas em diferentes bicicletas (tandens e convencionais), também parecem ter frustrado as expectativas do público e dos organizadores. Conforme registrou certa vez um artigo anônimo no jornal Correio do Norte, comentando uma disputa envolvendo uma bicicleta tandem e uma bicicleta convencional, a vantagem era tão grande para uma das bicicletas que se tornou fácil antecipar o resultado da corrida, diminuindo-lhe, portanto, o interesse. Segundo palavras publicadas no jornal: "foi uma desastrada e inepta desproporção na forma por que foi feito este páreo, cuja vantagem de um lado era tão grande que garantia juízo antecipado sobre o resultado da corrida". ${ }^{64}$ Enquanto isso, páreos dedicados exclusivamente às corridas a pé pareceram ter tido maior aceitação. Coriolano Durand, ciclista e cronista esportivo do Jornal do Commercio, no embalo do interesse despertado pelas competições de corrida a pé, logo escreveu artigos explicando técnicas de respiração e educação dos movimentos para o aprimoramento de ciclistas e corredores da cidade. ${ }^{65}$

\footnotetext{
${ }^{60}$ Velodromo Amazonense. Jornal do Commercio, Manaus, 20 de julho de 1906, n. 740, p. 3.

${ }^{61}$ Velodromo Amazonense. Jornal do Commercio, Manaus, 22 de abril de 1906, n. 651, p. 3.

${ }^{62}$ Velodromo. Correio do Norte, Manaus, 23 de maio de 1906, n. 104, p. 1.

${ }^{63}$ A Festa do Velódromo. Correio do Norte, Manaus, 1 de maio de 1906, n. 85, p. 1.

${ }^{64}$ Velodromo. Correio do Norte, Manaus, 27 de março de 1906, n. 56, p. 1.

${ }^{65}$ Sport. Jornal do Commercio, Manaus, 22 de abril de 1906, n. 651, p. 2.
} 
Em todas essas diferentes formas e modalidades de corrida, além da diversidade e inovação em si, buscava-se também a incerteza da vitória. Esta imprevisibilidade sobre o resultado das corridas, na medida em que era elemento importantíssimo para a geração de emoções, era apontada mesmo como a principal razão para o verdadeiro entusiasmo diante das disputas no velódromo, que coerentemente iam sendo chamadas então de "corridas de sensação". ${ }^{6}$ Assim, certo equilíbrio entre os competidores era indispensável para imprevisibilidade do resultado e consequente possibilidades de emoção, que por isso mesmo eram vistos como alguns dos principais elementos para o sucesso ou o fracasso de atividades do velódromo.

Identificar com precisão os motivos pelos quais o público aprovava ou desaprovava certas formas de competição era deveras importante para os organizadores dessas corridas, pois disso dependia grande parte do sucesso comercial de seus empreendimentos. Antes de ser um espaço para a promoção de práticas esportivas e difusão de hábitos saudáveis, os esportes em Manaus assumiam um caráter de empreendimento comercial para a oferta de diversão. Argumentos que apelavam para o caráter salutar da adoção da prática de esportes também estavam presentes em Manaus, alegando que esportes eram recursos valiosos para o fortalecimento da juventude e aprimoramento da "raça". Todavia, diante do modo de organização dos esportes naquele momento, tais argumentos pareciam muito mais um mero pretexto retórico para agregar legitimidade e relevância social a uma iniciativa que afinal era comercial e buscava antes de tudo o lucro, especialmente porque não permitia que a maioria dos envolvidos no espetáculo de fato se beneficiasse dos efeitos do esporte à saúde, já que eram apenas espectadores. A busca do lucro e da diversão, portanto, eram os elementos principais por trás do aparente crescimento do entusiasmo popular por esportes em Manaus de princípios do século 20.

Medida do novo entusiasmo que cercavam as corridas do Velódromo Amazonense era a notoriedade que começava a afetar certos esportistas envolvidos em tais competições. O mais proeminente deles nesse período, que chegou a ser comparado aos "melhores ciclistas do mundo", chamado em Manaus de "o senhor absoluto das pistas", que tinha inclusive exibições de fotografias em lojas da cidade, foi o ciclista e engenheiro civil Deodoro de

\footnotetext{
${ }^{66}$ Velodromo Amazonense. Jornal do Commercio, Manaus, 25 de maio de 1906, n. 684, p. 3; Velodromo Amazonense. Jornal do Commercio, Manaus, 16 de junho de 1906, n. 706, p. 3; Velodromo Amazonense. Jornal do Commercio, Manaus, 17 de junho de 1906, n. 707, p. 3.
} 
Alcântara Freire, mais conhecido pelo seu pseudônimo "Stoessel". ${ }^{67}$ Formado em engenharia na Bélgica, artigos em jornais de Manaus logo se apressaram em associar o gosto pelo ciclismo de Deodoro de Alcântara Freire a sua passagem para estudos na Europa. Todavia, esses mesmos jornais haviam registrado ainda nos idos de 1898, antes, portanto, de sua passagem pela Europa, a participação do futuro engenheiro em corridas infantis de bicicleta organizadas em Manaus pelo Grupo Ciclista, o que além de contrariar as afirmações sobre as origens supostamente europeias do seu gosto pelo ciclismo, estabelece ligações de continuidade entre as iniciativas no novo Velódromo Amazonense e o antigo Grupo Ciclista. A ênfase na narrativa de que teria sido na Europa que o engenheiro adquiriu o gosto pelo ciclismo era apenas mais um expediente retórico para ampliar a reputação não apenas deste ciclista, especificamente, mas do ciclismo, de um modo geral, dado que tudo que tivesse vínculos com a Europa assumia ares de superioridade.

Tendo se iniciado no ciclismo na Europa ou no Brasil, era certo, no entanto, que "Stoessel" de fato gozava de grande estima entre os entusiastas do esporte em Manaus no período. De acordo com comentários divulgados na imprensa local, sempre suspeitas em razão da sua aparência publicitária, algumas de suas corridas atraíam "elevadíssimo número de espectadores", como teriam sido os casos das disputas pelos recordes dos 500 e dos $10 \mathrm{mil}$ metros, em meados de 1906. Desta feita, conforme palavras publicadas no Jornal do Commercio, "a ansiedade da multidão que enchia o velódromo era imensa". A competição entre "Stoessel”, "Espalhado" e "Patagônia", segundo ainda o mesmo jornal, teria se desenrolado "em meio a um silêncio religioso" - querendo enfatizar a excitabilidade geral que permeava a plateia. Ao final, a vitória de "Stoessel", classificada como "brilhante", teria dado lugar a uma ovação "extraordinária", conforme registrou o jornal, cujo desfecho foi a condução triunfal do vencedor pelos seus admiradores até a sua residência. ${ }^{68}$

Nesse ambiente, corridas envolvendo ciclistas mais reputados, como "Stoessel", o esportista de Belém conhecido como "Alcebíades", o português conhecido por "Matozinhos" ou ainda o alemão Karl Schoeler, ganhavam mais destaque na imprensa e no esforço promocional dos diretores do velódromo, que as anunciavam de forma grandiloquente como "sucessos monumentais", "extraordinariamente colossais e atraentes". Para dimensionar, os prêmios das competições entre alguns desses ciclistas, que usualmente giravam entre

\footnotetext{
${ }^{67}$ Varias noticias. Jornal do Commercio, Manaus, 26 de outubro de 1905, n. 576, p. 1; Velodromo. Correio do Norte, Manaus, 17 de abril de 1906, n. 73, p. 1.

${ }^{68}$ Sport. Jornal do Commercio, Manaus, 17 de abril de 1906, n. 646, p. 2.
} 
$20 \$ 000$ e $70 \$ 000$ nessa época, chegaram a atingir o valor de $200 \$ 000$ - mais de quatro vezes o valor médio habitual, portanto. ${ }^{69}$

Outra inovação sob a direção de Britto Pereira foi a introdução das apostas, que passaram a ser anunciadas nos programas das corridas. Propagandas com o programa das corridas, aliás, publicadas em jornais de Manaus, especialmente no Jornal do Commercio, aumentaram de tamanho. Crônicas com os resultados dessas competições também ficaram maiores e mais detalhadas (sendo possível que fossem propagandas pagas pelos organizadores das corridas). Nessas propagandas, nota-se uma nova estrutura, tanto dos anúncios quanto das corridas, com mais ênfase sobre "as grandes atrações", além da divulgação dos preços, que passaram a ter quatro diferentes categorias: "geral", "arquibancada", "cavalheiro" e "carro de luxo" (crianças e mulheres não pagavam). Sorteios de brinde foram adotados como estratégia explicitamente endereçada para atrair o público feminino.

Em 1907, no terceiro e último ano de funcionamento do velódromo, novas mudanças foram implementadas por um novo diretor, que tinha um perfil ligeiramente diferente dos que lhe antecederam no cargo. Francisco d'Assis de Souza Guimarães, ao invés de proprietário de casas comerciais da cidade, fazia parte da "classe caixeiral", isto é, um trabalhador do comércio, conforme termos que usualmente se empregavam à época. Souza Guimarães era secretário da Associação dos Empregados no Comércio do Amazonas - que fora fundada em dezembro de 1906.

A presença de caixeiros no velódromo antecede a ascensão de Souza Guimarães à direção do local. Um caixeiro de nome Raymundo Tribuzy, por exemplo, atuara como juiz do velódromo desde antes, e é bastante provável que houvesse outros, se não atuando diretamente nas corridas, ao menos como parte do público do velódromo, de onde poderiam assistir as competições. Depois da chegada de Souza Guimarães à direção do velódromo, todavia, iniciativas tentando atrair grupos mais populares ao local parecem ter se expandido. Souza Guimarães liderou algumas ações claramente visando maior popularização do velódromo. 0 preço do ingresso para as arquibancadas sofreu redução de $25 \%$, passando de $4 \$ 000$ para $3 \$ 000 .^{70}$ Sorteios de brindes, que se consolidaram então como estratégia para atração de público, estenderam-se a outros grupos que não apenas as mulheres, especialmente as crianças, a quem se ofereciam brinquedos e bombons. Corridas em homenagem aos caixeiros, como o páreo "Fênix Caixeiral", parecem ter se tornado mais

\footnotetext{
${ }^{69}$ Velodromo Amazonense. Jornal do Commercio, Manaus, 25 de janeiro de 1907, n. 927, p. 3.

${ }^{70}$ Sport. Jornal do Commercio, Manaus, 25 de janeiro de 1907, n. 927, p. 2.
} 
frequentes nas programações. Além disso, seguindo a tendência de ampliação da complexidade organizacional das atividades realizadas ali, grupos de até 34 pessoas passaram a compor o quadro de juízes do velódromo (cujo número antes oscilou entre 10 e 20 , aproximadamente). ${ }^{71}$

O esforço de popularização também se nota na natureza das iniciativas que se organizaram no velódromo em 1907, que enfatizavam cada vez mais seus apelos como uma forma de entretenimento, ao invés de um costume salutar capaz de melhorar a saúde ou o grau de civilização de um povo. Nessa época, o caráter de entretenimento das corridas parece mesmo ter sido acentuado nas propagandas do velódromo vinculadas nos jornais da cidade. Se antes chamavam-nas já "corridas de sensação", agora eram as "corridas mirabolantes". De fato, tratavam-se agora de corridas com até quinze ciclistas (antes esse número oscilava entre três e seis), às vezes distribuídos por equipes com ciclistas estrangeiros, que representavam diferentes nacionalidades, em competições que podiam envolver a participação do público. As "corridas com obstáculos", as "provas de perseguição" e os "torneios das bonecas" eram todos exemplos nesse sentido.

As "corridas com obstáculos", como o nome já indica, eram competições ciclísticas convencionais, tal como as usualmente realizadas, acrescidas, porém, de obstáculos na pista. Propagandas anunciavam-nas como "torneio[s] de grande entusiasmo e hilaridade". ${ }^{72}$ As "provas de perseguição" eram competições em que os ciclistas se distribuíam pela pista a distâncias iguais. A competição, que durava 15 minutos, consistia em tentar ultrapassar os que estivessem imediatamente à sua frente, sendo eliminado o ciclista ultrapassado. A dinâmica seguia pelo tempo pré-determinado, na expectativa de que ao final restasse apenas um ciclista, que seria então declarado vencedor. ${ }^{73}$ Os "torneios das bonecas" consistiam em convidar mulheres da plateia para a pista, onde deveriam vestir roupas em bonecas. Enquanto isso, ciclistas iniciavam uma corrida ao redor da pista. Concluída a primeira volta, os ciclistas esperavam que as bonecas que lhes foram previamente atribuídas estivessem vestidas. Feito isso, as bonecas vestidas eram conduzidas pelos ciclistas em mais uma volta ao redor da pista. A boneca conduzida pelo ciclista que primeiro concluísse todo o processo era declarada "boneca vencedora", não sem antes ter a qualidade e o asseio de sua vestimenta examinada por um júri. A coisa toda era uma grande brincadeira, com um certo aspecto circense.

\footnotetext{
${ }^{71}$ Velodromo Amazonense. Jornal do Commercio, Manaus, 25 de janeiro de 1907, n. 927, p. 3.

${ }^{72}$ Sport. Jornal do Commercio, Manaus, 10 de março de 1907, n. 969, p. 2.

${ }^{73}$ Sport. Jornal do Commercio, Manaus, 17 de março de 1907, n. 976, p. 2.
} 
Apesar das mudanças para tornar o velódromo e suas corridas mais atraentes, além de talvez mais de acordo com o gosto de estratos populares, que poderiam aumentar a demanda pelo consumo de espetáculos esportivos, dado que ofereciam potencialmente público mais numeroso, já em 1907 o velódromo fechou as portas. Três fatores parecem ter determinado o destino do local. Primeiro, o próprio tempo de funcionamento do velódromo, pois depois do entusiasmo inicial com a novidade, que já orientava fortemente predileções nos lazeres populares naquela época, corridas de bicicletas em velódromos poderiam parecer enfadonhas para os espectadores, especialmente no momento em que novos aparatos tecnológicos ainda mais modernos e velozes, como os automóveis, prometiam atender melhor as demandas por mobilidade, velocidade e excitação dos sentidos que marcavam aquela época. ${ }^{74}$

Em segundo lugar, o fim das possibilidades de apostas nas corridas de bicicleta pode ter acelerado o desinteresse da população pelo esporte, tal como parece ter acontecido também no Rio de Janeiro no mesmo período. ${ }^{75}$ No Rio de Janeiro, aliás, desde meados da década de 1890 havia já proibições oficiais contra apostas nos esportes, especialmente no remo. ${ }^{76}$ Apostas continuaram parte importante do universo esportivo das corridas de cavalo, embora repressões contra intermediários tenham se exacerbado a partir daquela época. Em Manaus, apostas parecem ter sido abolidas das corridas de bicicletas no velódromo já em 1906 - mesmo ano em que teriam sido introduzidas. Logo já não seria possível encontrar menções a apostas nos programas e resultados das corridas realizadas no velódromo e publicadas nos jornais da cidade. Se apostas acaso continuaram sendo realizadas nesse contexto, foram de forma discreta ou talvez até ilegal.

Temores das elites diante do risco de desordem pública estimulavam uma "criminalização da vida cotidiana”, isto é, uma crescente regulação policial dos hábitos populares. Jogos, entretenimentos diversos, costumes religiosos e o comércio das ruas estiveram entre alguns dos principais alvos dessa repressão. ${ }^{77}$ Críticas ao comportamento aparentemente irracional do hábito de apostar em jogos cujos resultados não dependiam fundamentalmente das habilidades do jogador, mas sim da sorte, eram parte fundamental do corolário

\footnotetext{
${ }^{74}$ Sobre a predileção popular por novidades, ver DIAS, Cleber. Mercantilização do lazer no Brasil. Licere, Belo Horizonte, v. 21, p. 364-403, 2018. Sobre a atração de novos aparatos tecnológicos, ver Harmond, op. cit; Holt, op. cit.

${ }^{75} \mathrm{cf}$. Schetino, op. cit.

${ }^{76}$ Melo, 2001, op. cit.

${ }^{77}$ CHAZKEL, Amy. Leis da sorte: o jogo do bicho e a construção da vida pública urbana. Campinas: Ed. da Unicamp, 2014.
} 
dessa repressão. Nesse caso, reproduzia-se antigas restrições contra apostas e jogos de azar, que estavam fortemente presentes no imaginário do Brasil desde antes. De acordo com essa antiga escala de valores, nunca plenamente assimiladas pelo conjunto da população, como mostra o persistente costume popular em apostar, jogos estavam associados a vícios e a degradação moral. ${ }^{78}$ Além do medo puro e simples de insurreições populares, que marcaram preocupações das elites ao longo de todo o século 19, a hostilidade repressora diante dos jogos com apostas - e dos costumes populares de modo geral - expressava também interesses materiais e econômicos. Depois de articular um consenso moral que desqualificava o hábito de apostar, usualmente classificado como algo pervertido, rude e incivilizado, o uso do aparato legal e repressivo do Estado contra essas práticas tinha legitimidade pública. Todavia, mais que apenas a imposição de valores e visões de mundo, tratava-se de delimitar o espaço social em que os gastos com consumo poderiam se dar de maneira legal e legítima, visando, na prática, controlar o mercado e eliminar a concorrência. ${ }^{79}$ Finalmente, havia ainda a necessidade prática percebida pelas classes proprietárias de criar mecanismos de coerção que obrigassem uma grande massa de trabalhadores apenas recentemente libertados da escravidão a se sujeitarem a uma nova disciplina de trabalho assalariado. ${ }^{80}$ Nesse sentido, a ambição dos pobres em ganhar dinheiro seria desejável, desde que buscasse se realizar por meios compatíveis com os interesses das classes proprietárias, quais sejam, basicamente, o de dispor da força de trabalho dos mais pobres. Assim, apostas apareciam como algo pouco conveniente, pois ofereciam possibilidades de ganhos financeiros sem a necessidade do trabalho.

O terceiro e último aspecto que parece ter sido decisivo para o fim do Velódromo Amazonense foi o surgimento de um concorrente: o Prado Amazonense, onde aconteciam corridas de cavalo. ${ }^{81}$ Apesar de estar sob efeito de uma crescente prosperidade econômica gerada pela economia de extração e exportação da borracha, implicando, entre outras coisas, uma população e uma densidade urbana relativamente elevadas para os padrões brasileiros da época, Manaus, ainda assim, tinha um mercado consumidor pobre e limitado.

\footnotetext{
${ }^{78}$ SOUZA, Juliana Teixiera. Os jogos proibidos no tempo do Império. In: MARZANO, Andrea; MELO, Victor Andrade de (orgs.). Vida divertida: histórias do lazer no Rio de Janeiro (1830-1930). Rio de Janeiro: Apicuri, 2010, p. 153-178.

${ }^{79}$ Chazkel, 2014.

${ }^{80} \mathrm{cf}$. CHALHOUB, Sidney. Trabalho, lar e botequim: o cotidiano dos trabalhadores no Rio de Janeiro da belle époque. Campinas: Editora da Unicamp, 2001; LAMOUNIER, Maria Lúcia. Ferrovias e mercado de trabalho no Brasil do século XIX. São Paulo: Edusp, 2012.

${ }^{81}$ Sport. Jornal do Commercio, Manaus, 19 de abril de 1907, n. 1.008, p. 2.
} 
Boa parte da riqueza gerada pela economia da borracha concentrava-se nas mãos de grandes negociantes. Uma das consequências dessa concentração foi a relativa indisponibilidade de dinheiro na economia não apenas de Manaus, se não de toda a bacia amazônica. Boa parte dos negócios da região funcionavam baseados no crédito, isto é, em papéis que prometiam pagamento no futuro. Havia pouco dinheiro em espécie disponível e em circulação na Amazônia dessa época. Não por acaso, iniciativas para abertura de bancos na região, cujo objetivo era justamente contornar a escassez de capital na economia regional, não podiam se concretizar pela simples indisponibilidade de recursos. ${ }^{82}$ Em tais circunstâncias, o surgimento de um novo empreendimento para o entretenimento na cidade ampliava a concorrência e tendia a comprometer a viabilidade comercial dos que existiam antes, especialmente quando ambos ofereciam atividades dentro de um mesmo segmento, o dos espetáculos esportivos. O mercado consumidor da cidade não parecia grande e próspero o bastante para sustentar economicamente dois empreendimentos voltados a grandes públicos ao mesmo tempo, como eram o velódromo e o hipódromo.

\section{Considerações finais}

José Maranhão, um dos empresários por trás da inauguração do segundo velódromo de Manaus, esteve também envolvido na criação do primeiro hipódromo da cidade, construído a partir de 1905 e inaugurado em 1907, com o nome de Prado Amazonense. As informações de natureza empresariais de que dispomos sobre o funcionamento dessas iniciativas, porém, são bastante incompletas, o que impede conclusões mais assertivas a esse respeito, limitando-nos a apenas algumas deduções especulativas. Não está claro, por exemplo, se José Maranhão esteve envolvido nas duas iniciativas simultaneamente ou se embarcou na empreitada do hipódromo apenas depois de ter abandonado seus negócios no velódromo. A construção do hipódromo teve início em 1905, um ano depois, portanto, da inauguração do velódromo. No entanto, como vimos, nesse mesmo ano, José Maranhão foi substituído na direção do velódromo por Raymundo Pereira (que até então era secretário da empresa Manaus Sport). A mudança de direção do velódromo acaso indicava também mudança de direção da empresa que administrava o lugar? Em outras palavras, José Maranhão teria permanecido envolvido com a Manaus Sport depois de sua saída da direção do velódromo? Não sabemos.

${ }^{82}$ Weinstein, op. cit. 
Uma eventual venda da empresa ou de parte dela talvez lhe tivesse permitido liberação de capitais, que eram escassos em Manaus nessa época, para novos empreendimentos. Talvez Maranhão tenha notado o progressivo arrefecimento do entusiasmo do público pelas corridas de bicicleta, quando poderia ter decidido abandonar as atividades do velódromo e iniciar novos negócios com o hipódromo. Maranhão talvez intuísse que o simples fato das corridas de cavalo serem uma novidade na cidade podia garantir-lhe por algum tempo a presença do público interessado em novas oportunidades de diversão, ao menos até que outra novidade ainda mais recente se apresentasse e desviasse novamente a atenção desse público, como o surgimento de campos de futebol de fato logo faria a partir dos princípios de $1910 .^{83}$ Tudo isso, porém, não são mais que conjecturas.

Em todo o caso, o ano em que o hipódromo entrou em funcionamento coincidiu com o fim das atividades no velódromo, sugerindo que as duas atividades concorreram entre si, com o velódromo sucumbindo, no fim, diante da inauguração do hipódromo - ainda que não necessariamente por causa desta inauguração, dado que outros fatores podem ter influído neste colapso. Além disso, como destacamos antes e tentamos demonstrar ao longo do artigo, empresários estiveram entre um dos principais e primeiros grupos responsáveis pela expansão de oportunidades de consumo de serviços tais como os espetáculos esportivos.

Artigo recebido para publicação em 29/11/2019

Artigo aprovado para publicação em 13/08/2020

\footnotetext{
${ }^{83}$ NORMANDO, Tarcisio Serpa. Jogos de bola, projetos de sociedade: por uma história social do futebol na belle époque manaura. Dissertação (Mestrado em Sociedade e Cultura na Amazônia). Manaus: Universidade Federal do Amazonas, 2003.
} 